\title{
Implementasi Manajemen Berbasis Madrasah dalam Peningkatan Mutu Pendidikan di Madrasah
}

\author{
Karseno Handoyo $^{1 *}$, Mudhofir ${ }^{2)}$, Maslamah ${ }^{3)}$ \\ ${ }^{1,2,3}$ Institut Agama Islam Negeri (IAIN) Surakarta \\ *Email korespondensi: karsenohandoyo@gmail.com
}

The purpose of this study was to explore the uniqueness of the implementation of School Based Management (MBS) in Madrasahs. Madrasah education is interesting to study because after Pesantren, Madrasah became a reference for Islamic schools, which are formal schools with modern Islamic ideas. However, Madrasahs also have various problems related to quality and quality, both input and process and output. Using data from Madrasah Ibtidaiyah Negeri (MIN) 2 Sukoharjo and Madrasah Ibtidaiyah Negeri (MIN) 4 Sukoharjo, researchers will compare how the implementation of SBM in each Madrasah. Data collection techniques using interviews, documentation and field observations. The analysis technique used in the research is phenomenology, where the researcher tries to reveal the reality and experiences experienced by the individual, to understand something that is not visible from the individual's subjective experience. Researchers will go directly to the field, describe and construct existing realities and make approaches to information sources, so that it is hoped that the data obtained will be maximized. The research subjects were the principals of Madrasah Ibtidaiyah Negeri (MIN) 2 Sukoharjo and Madrasah Ibtidaiyah Negeri (MIN) 4 Sukoharjo, while the informants in this study were Deputy Heads, Administration, Teachers, Employees, Head of the Ministry of Religion of Sukoharjo Regency, Kasi who could provide information. about SBM policies, stakeholders and parents. The results of the research on the Concept of School-Based Sharia Management (MBS) implemented in Madrasah Ibtidaiyah Negeri 2 Sukoharjo and Madrasah Ibtidaiyah Negeri (MIN) 4 Sukoharjo are good enough. Some of the components in the SBM concept can be implemented well, such as the democratic leadership of the principal, the principal has been able to carry out the roles of educators, managers, leaders, administrators, supervisors, innovators and motivators well. In addition, the active role of the community has also been It seems that this can be seen with the assistance given to MIN 2 Sukoharjo and MIN 4 Sukoharjo both material and non-material.

\section{Kata kunci: School Based Management, Quality Education, Madrasah}

Saran sitasi: Handoyo, K., Maslamah., \& Mudhofir. (2021). Implementasi Manajemen Berbasis Madrasah dalam Peningkatan Mutu Pendidikan di Madrasah. Jurnal Ilmiah Ekonomi Islam, 7(01), 321-332. doi:http://dx.doi.org/10.29040/jiei.v7i1.1855

DOI: $\underline{\text { http://dx.doi.org/10.29040/jiei.v7i1.1855 }}$

\section{PENDAHULUAN}

Mutu dan tata kelola pendidikan merupakan masalah yang sering di bahas terutama bagi banyak negara berkembang. Terinspirasi dari model pembelajaran gaya Amerika yang focus pada desentralisasi, bentuk ideal Manajemen Berbasis Sekolah focus pada bagaimana pemberdayaan kepala sekolah dengan otonomi yang luas dan memiliki kontrol atas berbagai kegiatan sekolah seperti pembelajaran, pengembangan kurikulum, serta peningkatan mutu kompetensi pengajar (Lee \& Chiu, 2017). Manajemen Berbasis Sekolah (MBS) merupakan merupakan konsep manajemen di era otonomi daerah untuk meningkatkan mutu pendidikan. MBS muncul dalam dunia pendidikan yang berdampak pada pelaksanaan manajemen sekolah. Namun demikian desentralisasi diberbagai negara Asia Timur menurut penelitian ini secara umum lebih mengarah pada kemandirian sistem pembiayaan/pendanaan dibandingkan dengan kemandirian pada kurikulum pembelajaran dan mutu pembelajaran (Lee \& Chiu, 2017).

Pandangan lain oleh Aziz (2018) menjelaskan MBS memberikan otonomi lebih besar kepada 


\section{Jurnal Ilmiah Ekonomi Islam, 7(01), 2021, 322}

sekolah dan mendorong sekolah untuk melakukan pengambilan keputusan secara partisipatif untuk memenuhi tujuan mutu sekolah dalam kerangka pendidikan nasional. Otonomi tersebut akan memberikan keleluasaan sekolah untuk mengelola pendidikan bersama dengan standar pengelolaan dengan melibatkan komite madrasah yang terdiri dari unsur stakeholders, orang tua siswa, dan masyarakat (Patras et al., 2019), dimana masyarakat dan satuan pendidik memiliki keterlibatan aktif sesuai dengan kebutuhan pengembangan sekolah. Focus MBS adalah otonomi dalam pengambilan keputusan, ruang gerak yang luwes, pendekatan professional, memfasilitasi kebijakan, mengelola resiko, teamwork yang kompak dan cerdas serta pemberdayaan. Selanjutnya Patras et al., (2019) bahwa kontribusi penting MBS pada efektivitas layanan pendidikan secara keseluruhan seperti lingkungan yang sehat dan aman, meningkatnya motivasi peserta didik, kurikulum pembelajaran yang relevan, peningkatan kompetensi guru serta tata kelola pendidikan yang lebih baik serta hasil pembelajaran yang lebi akurat.

MBS merupakan strategi untuk menwujudkan sekolah/madrasah yang efektif dan produktif. MBS adalah desentralisasi level otoritas penyelenggaraan sekolah kepada level sekolah. Tanggung jawab dan pengambilan keputusan terhadap pelaksanaan dan penyelenggaraan sekolah telah diserahkan kepada kepala sekolah, guru-guru, para orang tua siswa, peserta didik atau siswa, dan anggota komunitas sekolah lainnya (Suparlan, 2013). MBS merupakan salah satu pendekatan yang dipilih di era desentralisasi sebagai alternatif peningkatan kualitas pendidikan (Aminah et al., 2015). Konsep MBS penentuan kebijakan harus ditetapkan oleh semua pemangku kepentingan (stakeholder) pendidikan di sekolah. Madrasah sebagai suatu lembaga di dalamnya mengatur tentang kegiatan pembelajaran yang tergambar bahwa proses pendidikan di Madrasah yang melibatkan kepala Madrasah. Madrasah memberi peluang bagi kepala Madrasah, guru, dan peseserta didik untuk melakukan inovasi dan improvisasi, baik pada kurikulum, proses pembelajaran, manajerial, pada aktivitas yang kreativitas, inovatif dan profesionalisme dengan keterlibatan masyarakat. (Athiyah, 2019).

Yahya (2015) meyatakan bahwa, Madrasah adalah sekolah umum yang berciri khas Islam. Pengertian ini menunjukkan bahwa dari segi materi kurikulum, madrasah mengajarkan pengetahuan umum yang sama dengan sekolah-sekolah umum sederajat. Hanya saja yang membedakan madrasah dengan lembaga pendidikan Madrasah dengan lembaga pendidikan umum adalah banyaknya pengetahuan agama yang diberikan, yang merupakan ciri khas Islam. Madrasah merupakan lembaga pendidikan yang mempunyai porsi lebih terhadap mata pelajaran agama khususnya Islam atau sering disebut dengan Sekolah Agama. Pada pelaksanaan MBS sekolah/madrasah dituntut secara mandiri untuk menggali dan mengalokasikan, menentukan prioritas, mengendalikan dan mempertanggungjawabkan pemberdayaan sumber daya yang dimiliki kepada masyarakat dan pemerintah (Patras et al., 2019).

Penelitian Yahya (2015) menyatakan bahwa Madrasah dianggap sebagai sekolah kelas dua, walaupun ada beberapa Madrasah yang justru lebih maju dibandingkan sekolah umum, namun secara jumlah keberhasilan beberapa Madrasah masih sangat terbatas dan belum mampu menghapus kesan negatif bahwa pendidikan Madrasah masih belum berkualitas. Yahya (2015) juga mengkritisi terkait dengan problematika komplek pendidikan di Madrasah seperti kualitas pendidik dan juga non pendidiknya, kurikulum pembelajaran, sarana dan prasarana yang memadahi, serta pendanaan. Apalagi secara umum Madrasah sebagian besar berstatus sekolah swasta sehingga berbagai problem terkait dengan kesejahteraan dan ketersediaan sarana prasaran yang memadahi masih menjadi kendala. Penyebab lain yang menyebabkan masih rendahnya mutu pendidikan antara lain: 1) masih ada guru yang kurang professional dibidangnya, seperti adanya guru yang terlambat masuk mengajar; 2) tidak mempunyai perangkat pembelajaran yang lengkap; 3) tidak memiliki media pembelajaran sebagai alat menjelaskan materi pembelajaran; 4) kurangnya koordinasi antara kepala sekolah dan guru, kepala sekolah kurang memberikan penghargaan bagi guru yang professional (Sulaiman et al., 2015). Diperkuat oleh Maimun \& Fitri (2010) selain problematika terkait dengan kualitas tenaga pengajar dan kurikulum, Madrasah juga juga memiliki masalah dengan kondisi sarana prasarana, input siswa, strategi pembelajaran dan juga keterbatasan pendanaan. Seperti kurikulum belum focus dan cenderung overload, strategi pembelajaran yang masih dikatakan sebagai warisan bukan pada problem solving, sarana prasarana yang jauh dari kata memadahi, dan juga dari segi prestasi yang masih jauh dibawah sekolah umum. 
Praktik manajemen di madrasah sering menunjukkan model manajemen paternalistik atau feodalistik (Maya \& Lesmana, 2018). Dominasi senioritas terkadang juga menganggu perkembangan dan peningkatan kualitas pendidikan di Madrasah.

Tujuan penelitian ini adalah bagaimana implementasi MBS dalam peningkatan mutu sekolah/Madrasah. Indikator peningkatan mutu pendidikan dapat ditingkatkan apabila sekolah/madrasah memiliki: 1) dukungan dari pemerintah; 2) kepemimpinan Kepala sekolah yang efektif; 3) kinerja guru yang baik; 4) kurikulum yang relevan; 5) lulusan yang berkualitas; 6) budaya dan iklim organisasi yang efektif; 7) dukungan masyarakat dan orang tua siswa (Fadhli, 2017). Selanjutnya menurut Sunanto (2015) penyebab rendahnya mutu pendidikan yaitu minimnya peran serta masyarakat dalam menentukan kebijakan sekolah sebagai akibat masyarakat kurang merasa memiliki, kurang tanggung jawab dalam memelihara dan membina sekolah dimana anak-anaknya bersekolah. Selanjutnya hasil penelitian Ahmad Zaini Aziz (2015) bahwa basis dari MBS adalah desentralisasi dan menariknya bahwa Madrasah merupakan lembaga pendidikan yang berada di bawah naungan Departemen Agama dengan sistem sentralisasi. Oleh karenanya, tulisan ini juga berusaha mengkaji kemungkinan Madrasah dapat mengimplementasikan Manajemen Berbasis Sekolah sebagai sebuah alternatif peningkatan mutu pendidikan Madrasah.

Keberadaan MI di Kabupaten Sukoharjo baik swasta atau negeri yang berjumlah hampir 80 Madrasah dan tersebar di Seluruh pelosok Kota Sukoharjo, akan bisa berkembang, dan bertahan serta akan menjadi rujukan Masyarakat, jika bisa mengelola Manajemennya dengan baik, yaitu dengan menggunakan Manajemen Berbasis Madrasah (MBS/M). Khusus untuk MI yang Negeri yang berada di Kabupaten Sukoharjo kiranya ini adalah sebuah tawaran yang segera perlu direspon secara cepat oleh semua pihak, karena pengelolaan Madrasah dengan MBS adalah solusi agar tidak tergantung terhadap kebijakan kebijakan pemerintah khususnya dalam hal pembiayaan, hal ini akan berdampak signifikan bagi percepatan perkembangan perkembangan bagi MI di Sukoharjo. Fakta dilapangan menunjukan bahwa Madrasah Ibtidaiyah di Kabupaten Sukoharjo yang berjumlah 6 Madrasah yaitu MIN 1 Sukoharjo, MIN 2 Sukoharjo, MIN 3 Sukoharjo, MIN 4 Sukoharjo, MIN 5 Sukoharjo dan MIN 6 Sukoharjo sangat berkembang dengan pesat setelah menggunakan sistem MBS, terlepas adanya perbedaan dalam masing pengelolaannya, karena dari ke enam madrasah tersebut mempunyai kelebihan dan kekurangan dalam mengimplementasikan MBS, ada yang berhasil dalam memaksimalkan peran serta masyarakat secara aktif dalam hal pembiyaan tetapi belum bisa memanajemen keuangan dengan baik, ada yang berhasil memaksimalkan keuangan dengan baik tetapi dalam hal peningkatan prestasi siswa belum bisa maksimal, ada yang bisa memaksimalkan dalam hal keuangan prestasi, keuangan, dan partisipasi masyarakat secara aktif tapi tidak maksimal di kurikulum dan program pengajaran. Adanya perbedaan hasil dari pelaksanaan MBS ini dikarena adanya faktor pendukung dan faktor penghambat di MIN Seluruh sukoharjo berbeda beda.

\section{KAJIAN TEORI}

\section{Manajemen Sekolah/Madrasah}

Menurut Erdiyanto et al., (2020) peran manajemen pendidikan adalah menentukan arah dan tujuan pendidikan, dengan memobilitasi Sumber Daya Manusia untuk mencapai tujuan. Sejalan dengan pandangan Nur et al., (2016) menjelaskan bahwa manajemen sekolah adalah dimana sekumpulan sumber daya manusia yang ada di sekolah menjadi pelaksana berdasarkan pada pembagian tugas yang telah ditentukan dan saling bekerjasama untuk mencapai tujuan pendidikan dan tujuan sekolah yang diharapkan. Berdasarkan pemaparan tersebut, disintesis bahwa manajemen sekolah adalah penerapan konsep dan fungsi-fungsi manajemen ke dalam proses pengelolaan sekolah sesuai dengan tujuan yang ingin dicapai oleh sekolah. Manajemen sekolah ini dimaksudkan untuk dapat memenuhi kebutuhan stakeholder, sehingga seluruh proses dan tahapannya mulai dari perencanaan, pengorganisasian, pengarahan, dan pengendalian dimaksudkan untuk dapat menyesuaikan dengan harapan sekolah dan para stakeholder (Aziz, 2018; Patras et al., 2019).

Manajemen madrasah adalah segala usaha bersama untuk mendayagunakan sumber daya madrasah baik personal maupun material secara efektif dan efisien guna menunjang tercapainnya tujuan madrasah secara optimal. Hal ini menunjukkan bahwa aktivitas di madrasah perlu dilakukan dengan manajemen yang baik atau secara efektif dan efisien. Dengan manajemen yang baik, maka tentunya aktivitas madrasah akan berjalan lancar, pendidikan 
dan pengajaran yang berkualitas, serta hal positif lainnya yang dapat diraih dari penerapan manajemen madrasah secara efektif (Khoiri, 2014). Manajemen madrasah merupakan strategi untuk mewujudkan madrasah yang efektif dan produktif. Manajemen madrasah yang efektif adalah pengelolaan, penataan, dan penyelenggaraan madrasah yang terprogram, terencana secara baik, terkoordinir, terintegrasi, termonitoring, dan terevaluasi serta terorganisasi secara terpadu dengan baik, lancar, dan dilaksanakan dengan cepat waktu, tepat teknik cara dan strategi serta dilaksanakan oleh orang yang tepat pula. Kemampuan organisasi untuk berubah ditentukan oleh seberapa berdayanya personel organisasi dalam melakukan perubahan. Konsep employee empowerment menjadi prasyarat untuk membangun suatu organisasi yang mampu beradaptasi dengan cepat, bahkan dengan cepat telah terjadi atau potensial yang akan terjadi. Pandangan Arif, (2013) Madrasah harusnya menjadi lembaga maju, karena kemajuan Madrasah akan berpengaruh pada pilihan orang tua murid untuk menyekolahkan anaknya. Untuk memajukan Madrasah terdapat lima daya dongkrak yang yang harus dipenuhi oleh Madrasah seperti aspek manajemen, kompetensi / Sumber Daya guru, pemanfaatan tehnologi internet dan model pembelajaran, budaya teamwork dan pemanfaatan alat bantu dalam proses pembelajaran.

\section{Decentralization Pendidikan}

Prinsip desentralisasi dilintasi oleh teori dasar bahwa pengelolaan sekolah dan aktivitas pengajaran tak dapat dielekakan dari kesultian dan permasalahan. Pendidikan adalah masalah yang rumit dan kompleks sehingga memerlukan desentralisasi dalam pelaksanaannya. Prinsip ekuifinalitas yang dikemukakan sebelum mendorong adanya desentralisasi kekuasaan dengan mempersilahkan sekolahmemiliki ruang yang lebih luas untuk bergerak, berkembang, dan bekerja menurut strategistrategi unik mereka untuk menjalani dan mengelola sekolahnya secara efektif. Oleh karena itu, sekolah harus diberi kekuasaan dan tanggung jawab untuk memecahkan memecahkan masalahnya secara efektif dan secepat mungkin ketika masalah itu muncul. Dengan kata lain, tujuan dari prinsip desentralisasi adalah efisiensi dalam pemecahan masalah, bukan menghindari masalah. Oleh karena itu, manajemen sekolah bermutu harus mampu menemukan masala, memecahkannya tepat waktu dan memberi sumbangan yang lebih besar terhadap efektivitas pengajaran dan pembelajaran. Tanpa adanya desentralisasi kewenangan sekolah tidak dapat dilaksanakn peserta didikan dan akan berakibat terlambatnya pemecahan masalah secara cepat, tepat, dan efisien.

Manajemen sekolah yang bermutu harus menyadari bahwa pentingnya mempersilahkan sekolah menjadi sistem pengelolaan secara mandiri di bawah kebijakannya sendiri. Sekolah memiliki otonomi tertentu untuk mengembangkan tujuan pengajaran strategi manajemen, distribusi sumber daya manusia dan sumber daya lainnya, memecahkan masalah, dan mencapai tujuan berdasarkan kondisi mereka masing-masing sesuai dengan SDM dan kemampuannya. Karena sekolah dikelola secara mandiri maka sekolah lebih memiliki inisiatif dan tanggung jawab sendiri. Prinsip ini terkait dengan prinsip sebelumnya, yaitu prinsip ekuifinalitas dan prinsip desentralisasi. Ketika sekolah menghadai permasalahan maka harus diselesaikan dengan caranya sendiri. Sekolah dapat menyelesaikan masalahnya bila telah terjadi pelimpahan wewenang dari birokrasi di atasnya ke tingkat sekolah. Dengan adanya kewenangan di tingkat sekolah itulah maka sekolah dapat melakukan sistem pengelolaan mandiri.

Perspektif sumber daya manusia menekankan bahwa orang adalah sumber daya berharga di dalam organisasi sehingga poin utama manajeman adalah mengembangkan sumber daya manusia di adalam sekolah untuk berinisitatif. Berdasarkan perspektif ini maka Manajemen Sekolah bertujuan untuk membangun lingkungan yang sesuai untuk warga sekolah agar dapat bekerja dengan baik dan mengembangkan potensinya. Oleh karena itu, peningkatan kualitas pendidikan dapat diukur dari perkembangan aspek sumber daya manusianya. Prinsip ini mengakui bahwa manusia bukanlah sumber daya yang statis, melainkan dinamis. Oleh karena itu, potensi sumber daya manusia harus selalu digali, ditemukan, dan kemudian dikembangkan. Sekolah dan lembaga pendidikan yang lebih luas tidak dapat lagi menggunakan istilah staffing yang konotasinya hanya mengelola manusia sebagai barang yang statis. Lembaga pendidikan harus menggunakan pendekatan human resources development yang memiliki konotasi dinamis dan aset yang amat penting dan memiliki potensi untuk terus dikembangkan.

\section{Manajemen Berbasis Sekolah}

MBS adalah desentralisasi level otoritas penyelenggaraan sekolah kepada level sekolah. MBS 


\section{Jurnal Ilmiah Ekonomi Islam, 7(01), 2021, 325}

merupakan bentuk desentralisasi dalam manajemen pendidikan dengan pelimpahan wewenang dan pengambilan kebijakan dari pemerintah pusat/daerah atau birokrasi kepada pengelola sekolah secara langsung dan melibatkan orang tua murid. Bahkan dalam pengambilan kebijakan di sekolah, siswa pun harus dilibatkan. Tanggungjawab dan pengambilan keputusan terhadap pelaksanaan atau penyelenggaraan sekolah telah diserahkan kepada kepala sekolah, guru-guru, para orang tua siswa, kadang-kadang peserta didik atau siswa, dan anggota komunitas sekolah yang lainnya (Suparlan, 2013). MBS menyediakan para kepala sekolah, guru-guru, para siswa, dan para orang tua siswa, untuk melakukan pengawasan secara lebih besar terhadap proses pendidikan dengan memberikan tanggungjawab untuk pengambilan tentang anggaran, pernonel, dan kurikulum (Aziz, 2018).

Motif penerapan MBS di sekolah tidak terlepas dari latar belakang penyebab munculnya konsep tersebut. Setidaknya terdapat delapan motif penerapan MBS, yaitu motif ekonomi, profesional, politis, efisiensi administrasi, finansial, prestasi siswa, akuntabilitas, dan efektivitas sekolah. Peningkatan prestasi siswa meruapakan motif utama dari MBS. Sebab kualitas pendidikan dapat dilihat dari prestasi siswa di suatu sekolah. Jika prestasi siswa yang diraih cukup baik, maka kualitas sekolah itu pun bisa dikatakan baik pula. Untuk meningkatkan prestasi siswa, maka berbagai persoalan yang menghambat proses belajar mengajar dapat dipecahkan bersama dan diperoleh keputusan yang tepat. Oleh karena itu dalam MBS, kepala sekolah, guru, staf, orang tua, dan siswa pun dilibatkan dalam pengambilan keputusan (Yahya, 2015). Karena kewenangan luas yang dimiliki pengelola sekolah dalam mengambil keputusan, maka secara tidak langsung MBS mempunyai motif akuntabilitas sekolah. Sehingga pengelolaan sekolah akan berjalan efektif.

Tujuan MBS bermuara pada peningkatan mutu pendidikan, efisiensi, mutu pendidikan, dan pemerataan pendidikan. Dengan tujuan untuk memandirikan sekolah atau memberdayakan sekolah melalui pemberian kewenangan secara otonom kepada sekolah dan mendorong sekolah untuk melakukan pengambilan keputusan secara partisipatif dalam kerangka peningkatan kualitas pendidikan. Prinsip-Prinsip MBS dalam mengelola sekolah, yaitu: (a) prinsip ekuifinalitas didasarkan pada teori manajemen modern yang berasumsi, bahwa terdapat beberapa metode yang berbeda untuk mencapai suatu tujuan. Prinsip desentalisasi (principal of decentralization). Desentralisasi adalah gejala yang penting dalam reformasi manajemen sekolah modern. Prinsip ini konsisten dengan prinsip ekuifinalitas (Arif, 2013; Munajat, 2016). Ketiga, prinsip sistem pengelolaan mandiri. MBS menyadari pentingnya sekolah mendisain sistem pengelolaan secara mandiri di bawah kebijakan sendiri yang memiliki otonomi untuk mengembangkan tujuan pembelajaran, strategi manajemen, dan dumber daya lainnya (Khoiri, 2014). Keempat, prinsip inisiatif manusia. Sejalan dengan perkembangan pergerakan hubungan antar manusia dan pergerakan ilmu perilaku pada manajemen modern, manusia mulai menaruh perhatian serius pada pengaruh penting faktor manusia pada efektivitas organisasi.

Karakteristik MBS bisa diketahui antara lain dari bagaimana sekolah dapat mengoptimalkan kinerjanya, proses pembelajaran, pengelolan sumber belajar, profesionalisme tenaga kependidikan, serta sistem administrasi secara keseluruhan. Sejalan dengan (Khoiri, 2014) berdasarkan pelaksanaan di negara maju mengemukakan bahwa karakteristik dasar MBS adalah pemberian otonomi yang luas kepada sekolah, partisipasi masyarakat dan orang tua peserta didik yang tinggi, kepemimpinan sekolah yang demokratis dan profesional, serta adanya team work yang tinggi dan profesional. Diperkuat oleh Munajat (2016) pengembangan sekolah berbasis Madrasah mendukung tercapainya tujuan pendidikan dengan menciptakan lingkungan Madrasah yang terbuka, demokratis dan mendorong keterlbatan berbagai komponen dalam pengambilan keputusan.

\section{Manajemen mutu pendidikan}

Mutu mengandung makna derajat (tingkat) keunggulan suatu produk (hasil kerja/upaya baik berupa barang maupun jasa, baik yang tangible maupun intangible (Suryosubroto, 2004:210). Berdasakan terminologi tersebut menunjukkan bahwa mutu adalah paduan sifat dari barang atau jasa yang menunjukkan kemampuannya dalam memenuhi kebutuhan pelanggan baik kebutuhan yang dinyatakan maupun yang tersirat. Pengertian kualitas atau mutu dapat dilihat juga dari konsep secara absolut dan relatif. Dalam konsep absolut sesuatu (barang) disebut berkualitas bila memenuhi standar tertinggi sempurna. Artinya, barang tersebut sudah tidak ada yang melebihi. Bila diterapkan dalam dunia pendidikan konsep kualitas absolut ini bersifat elistis karena 


\section{Jurnal Ilmiah Ekonomi Islam, 7(01), 2021, 326}

hanya sedikit lembaga pendidikan yang akan mampu menawarkan kualitas tertinggi kepada pesera didik dan hanya sedikit peserta didik yang akan mampu membayarnya. Sedangkan dalam konsep relatif kualitas berarti memenuhi spesifikasi yang ditetapkan dan sesuai dengan tujuan (fit for their purpose). Kualitas dalam konsep relatif berhubungan dengan produsen, maka kualitas berarti sesuai dengan spesifikasi yang ditetapkan pelanggan (Sallis, 1993:51-53).

Mutu pendidikan adalah gambaran dan karakteristik menyeluruh jasa pelayanan pendidikan secara internal maupun eksternal yang menunjukkan kemampuannya memuaskan kebutuhan yang diharapkan atau yang tersirat mencakup input, proses, dan output pendidikan. Dalam konteks mutu pendidikan, pada hakikatnya tujuan lembaga pendidikan adalah untuk menciptakan dan mempertahankan kepuasan para pelanggan dan dalam kepuasan pelanggan ditentukan oleh stakeholder lembaga pendidikan tersebut. Oleh karena hanya memahami proses dan kepuasan pelanggan maka lembaga dapat menyadari dan menghargai kualitas. Semua usaha atau kegiatan manajemen mutu harus diarahkan pada suatu tujuan utama, yaitu kepuasan pelanggan, apa yang dilakukan manajemen tidak ada gunanya apabila tidak melahirkan kepuasan pelanggan.

Mutu pendidikan dapat dilihat dalam tiga hal, yakni input (masukan), proses, dan output (keluaran) (Rohiat, 2010:52). Input pendidikan adalah segala sesuatu yang harus tersedia karena dibutuhkan untuk berlangsungnya proses. Sesuatu yang dimaksudkan berupa sumber daya dan perangkat lunak serta harapan sebagai pemandu bagi berlangsungnya proses. Sesuatu yang dimaksud berupa sumber daya dan perangkat lunak serta harapan sebagai pemandu bagi berlangsungnya proses. input sumber daya manusia meliputi (kepala sekolah, guru, karyawan, dan peserta didik) dan sumber daya selebihnya (peralatan, perlengkapan, uang, dan bahan). Input perangkat lunak meliputi (struktur organisasi sekolah, peraturan perundang-undangan, deskripsi tugas, rencana, program) input harapan berupa (visi, misi, tujuan, dan sasaran-sasaran yang ingin dicapai sekolah). Oleh karena itu, tinggi rendahnya mutu input dapat diukur dari tingkat kesiapan input. Makin tinggi tingkat kesiapan input, makin tinggi pula mutu input tersebut.
Mutu pendidikan harus diupayakan untuk mencapai kemajuan yang dilandasi oleh suatu perubahan terencana. Meningkatkan mutu sekolah dapat pula melalui beberapa cara, seperti: 1) meningkatkan ukuran prestasi akademik melalui Ujian Nasional atau Ujian Daerah yang menyangkut kompetensi dan pengetahuan, memperbaiki tes bakat, sertifikasi kompetensi da profil portofolio; 2) membentuk kelompok sebaya untuk meningkatkan gairah pembelajaran melalui belajar secara kooperatif; 3) menciptakan kesempatan baru di sekolah dengan mengubah jam sekolah menjadi pusat belajar sepanjang hari dan tetap membuka sekolah pada jam libur; 4) meningkatkan pemahaman dan penghargaan belajar melalui penguasaan materi dan penghargaan atas pencapaian prestasi akademik; 5) membantu peserta didik memperoleh pekerjaan dengan menawarkan kursus yang berkaitan dengan ketrampilan memperoleh pekerjaan (Nurkholis, 2003: 78-79).

Salah satu usaha pemerintah untuk meningkatkan mutu pendidikan adalah dengan diadakannya otonomi pendidikan, otonomi diberikan agar sekolah dapat leluasa mengelola sumber daya sesuai dengan prioritas kebutuhan serta agar sekolah lebih tanggap terhadap kebutuhan lingkungan setempat (Hasbullah, 2006 : 82). Untuk mencapai hasil yang lebih optimal, efektif dan efisien dalam menangani berbagai permasalahan pendidikan, pemerintah daerah tidak mungkin dapat bekerja secara sendirian, karena masih ada pihak-pihak lain yang berkepentingan terhadap bidang pendidikan tersebut, seperti orang tua (masyarakat), sekolah (lembaga pendidikan), dan institusi sosial lain. Karena itu kerja sama pihak yang berkepentingan tersebut menjadi sangat penting dalam rangka pelaksanaan asas desentralisasi, terutama dalam bidang pengelolaan pendidikan. Strategi pengelolaan pendidikan yang mengedepankan kerjasama antara berbagai pihak seperti di atas saat ini lebih dikenal dengan istilah Manajemen Berbasis Sekolah (MBS) (Suryosubroto, 2004 : 195).

Manajemen Peningkatan Mutu Berbasis Madrasah perlu diterapkan untuk dijadikan solusi terhadap berbagai macam persoalan yang dihadapi Madrasah. Sejauh penelusuran penulis rendahnya kualitas Madrasah disebabkan oleh adanya diskriminasi madrasah, penyelenggaraan pendidikan yang birokrasi-sentralistik, ketidak tepatan kebijkan dan keputusan pemerintah terhadap peningkatan mutu madrasah, dan adanya disharmoni antara madrasah, 
pemerintah, dan masyarakat. Melihat berbagai persoalan yang dihadapi madrasah, tepat kirannya jika Manajemen Peningkatan Mutu Berbasis Madrasah diterapkan di madrasah sebagai jawaban atas problem yang ada, dengan tetap berada di bawah kendali dan kontrol pemerintah pusat, sehingga tujuan pendidikan madrasah akan tercapai, jika demikian maka madrasah akan menjadi lembaga pendidikan Islam yang bermutu dan berkualitas (Anwar, 2018 : 216). Konsep MBS merupakan kebijakan baru yang sejalan dengan paradigma desentralisasi dalam pemerintahan. Strategi apa yang diharapkan agar penerapan MBS dapat benar-benar meningkatkan mutu pendidikan (Suparlan, 2013 : 58-59).

Pertama, salah satu strategi adalah menciptakan prakondisi yang kondusif untuk dapat menerapkan MBS, yakni, peningkatan kapasitas dan komitmen seluruh warga sekolah, termasuk masyarakat dan orang tua siswa. Upaya untuk memperkuat peran kepala sekolah harus menjadi kebijakan yang mengiringi penerapan kebijakan MBS. "An essential point is that schools and teachers will need capacity building if school-based management is to work". Demikian De Grouwe menegaskan. Kedua, membangun budaya sekolah (school culture) yang demokratis, transparan, dan akuntabel. Termasuk membiasakan sekolah untuk membuat laporan pertanggung jawaban kepada masyarakat. Model memanjangkan RAPBS di papan penggumuman sekolah yang dilakukan oleh Managing Basic Education (MBE) meruapakan tahap awal yang sangat positif. Juga membuat laporan secara insidental berupa booklet, leaflet, atau poster tentang rencana kegiatan sekolah. Alangkah serasinya jika kepala sekolah dan ketua Komite Sekolah dapat tampil bersama dalam media tersebut. Ketiga, pemerintah pusat lebih memainkan peran monitoting dan evaluasi. Dengan kata lain, pemerintah pusat dan pemerintah daerah perlu melakukan kegiatan bersama dalam rangka monitoring dan evaluasi pelaksanaan MBS, di sekolah, termasuk pelaksanaan block grant yang diterima sekolah. Keempat, menegembangkan model program pemberdayaan sekolah. Bukan hanya sekedar melakukan pelatihan MBS, yang lebih banyak dipenuhi dengan pemberian informasi kepada sekolah. Model pemberdayaan sekolah berupa pendampingan atau fasilitasi dinilai lebih memberikan hasil yang lebih nyata dibandingkan dengan pola-pola lama berupa penataran MBS.
Manajemen Berbasis Sekolah telah banyak diterapkan di sekolah, bukan hanya di negara maju, tetapi juga telah menyebar di negara berkembang. Penerapan MBS telah banyak menjanjikan untuk peningkatan mutu pendidikan. Penerapan MBS akan berhasil jika diberikan prakondisi dengan membangun kapasitas dan komitmen sekolah, termasuk semua pemangku kepentingan, yang memiliki tanggung jawab bersama terhadap upaya peningkatan mutu pendidikan. Keberhasilan sekolah dalam menerapkan MBS dipengaruhi oleh kepedulian pemerintah pusat dan daerah untuk mendorong dan memberikan kesempatan sekolah menerapkan MBS di sekolah.

\section{METODE PENELITIAN}

\section{Setting Penelitian}

Untuk mempermudah dalam penelitian perlu ditentukan arah dan pembatasan terhadap daerahdaerah dan objek penelitian. Hal ini dilakukan untuk menjaga dan menghindari agar tidak terjadi kesimpangsiuran sehingga data yang diperoleh dapat dipertanggungjawabkan kebenarannya. Penelitian ini dilaksanakan Madrasah Ibtidaiyah Negeri (MIN) di Kabupaten Sukoharjo. Jumlah MIN yang ada di Kabupaten Sukoharjo ada MIN 1, MIN 2, MIN 3, MIN 4, MIN 5, dan MIN 6. Subyek penelitian adalah orang yang menjadi sumber utama dalam penelitian. Subyek atau sumber utama dalam penelitian ini adalah Kepala Madrasah Ibtidaiyah Negeri (MIN ) 2 Sukoharjo dan Madrasah Ibtidaiyah Negeri (MIN) 4 Sukoharjo. Informan penelitian adalah orang yang dapat memberikan informasi tambahan terkait dengan penelitian yang dilaksanakan. Penentuan informan yang menjadi sumber data dilakukan secara purposive yaitu dipilih dengan pertimbangan tertentu atau criterion based selection. Adapun informan dalam penelitian ini adalah Wakil kepala, Tata Usaha, Guru, Karyawan, Kepala Kemenag Kebupaten Sukoharjo, Kasi yang dapat memberikan informasi tentang kebijakan MBS.

\section{Metode Pengumpulan Data}

Pengumpulan data penting artinya dalam suatu penelitian, sebab data menjadi dasar dan alat untuk mencapai tujuan penelitian. Untuk memperoleh data yang diperlukan digunakan beberapa metode yang sekiranya sesuai dengan masalah yang diteliti. Dalam metode pengumpulan data ini, peneliti menggunakan metode kualitatif partisipatif (fieldwork relation). Di sinilah diperlukan kehadiran peneliti untuk tahu 
langsung kondisi dan fenomena di lapangan, tidak cukup meminta bantuan orang atau sebatas mendengar penuturan secara jarak jauh (Danim, 2002: 122). Pada tahap ini, peneliti menggunakan tiga macam metode atau teknik pengumpulan data, yaitu: Observasi dimaksudkan sebagai pengamatan dan pencatatan dengan sistematis terhadap fenomena-fenomena yang diselidiki. Atau dengan kata lain cara-cara mengungkapkan data yang dilakukan dengan mengamati dan mencatat gejala-gejala yang sedang diselidiki tentang observasi ini penulis menggunakan kerangka faktor-faktor yang diatur atau dikategorikan terlebih dahulu (Sutrisno Hadi, 1994 : 136).

Wawancara merupakan teknik pengumpulan data yang sesuai berdasarkan laporan verbal di mana pada wawancara ini terdapat dialog yang dilakukan oleh interviewer (pewawancara) untuk memperoleh informasi dari interview (orang yang diwawancarai) (Arikunto, 1993:115). Dalam hal ini, peneliti melakukan wawancara untuk mendapat informasi dari Wakil kepala, Tata Usaha, Guru, Karyawan, Kepala Kemenag Kebupaten Sukoharjo, Kasi yang dapat memberikan informasi tentang kebijakan MBS. Metode dokumentasi yaitu mencari data mengenai hal-hal yang variabel berupa catatan-catatan, transkip, buku, notulen, rapat, agenda, dan sebagainya (Arikunto, 2002: 236). Penggunaan dokumentasi bermanfaat dalam mengumpulkan informasi tentang Implementasi Manajemen Berbasis Sekolah MIN, khususnya yang berhubungan dengan arsip-arsip tentang Manajemen Berbasis Sekolah.

\section{Pemeriksaan Keabsahan Data}

Keabsahan data adalah usaha meningkatkan derajat kepercayaan data apakah data tersebut dapat dipertanggung jawabkan atau tidak. Untuk meningkatkan derajat keabsahan data agar dapat dipertanggung jawabkan secara optimal maka perlu ada uji keabsahan data. Uji keabsahan data dilakukan dengan memperpanjang partisipasi, ketekunan pengamatan, triangulasi, pengecekan sejawat, kajian kasus negative dan pengecekan anggota (Molleong, 2007:324). Triangulasi, adalah teknik pemeriksaan keabsahan data yang memanfaatkan sesuatu yang lain diluar data untuk keperluan pengecekan atau sebagai pembanding data tersebut (Molleong, 2007: 330). Sugiyono (2012: 241) membagi triangulasi menjadi dua yaitu triangulasi teknik dan triangulasi sumber.

Metode yang digunakan untuk memeriksa keabsahan data adalah dengan triangulasi method yaitu dengan memanfaatkan berbagai metode sebagai pertimbangan. Triangulasi ini dilakukan dengan jalan membandingkan dan mengecek informasi atau data yang diperoleh dari dokumentasi dengan hasil pengamatan dan interview (Moleong, 2014 :330). Triangulasi ini dilakukan dengan; (1) membandingkan data hasil pengamatan dengan data hasil wawancara, (2) membandingkan apa yang dikatakan orang di depan umum dengan yang dikatakan pribadi, (3) membandingkan apa yang dikatakan orang tentang situasi penelitian dengan apa yang didapat selama penelitian, (4) membandingkan keadaan dan perspektif seseorang dengan berbagai pendapat dan pandangan yang lain, dan (5) membandingkan hasil wawancara dengan isi suatudokumen yang berkaitan. Dengan kata lain bahwa peneliti dapat merecheck temuannya dengan jalan membandingkannya dengan triangulasi. Untuk itu peneliti perlu melakukan; (1) mengajukan berbagai macam variasi pertanyaan, (2) mengeceknya dengan berbagai sumber data, dan (3) memanfaatkan berbagai metode agar pengecekan kepercayaan data dapat dilakukan.

\section{HASIL PENELITIAN}

\section{Implmentasi Manajamen Syariah Berbasis Sekolah (MBS) di Madrasah}

Strategi Implementasi Manajemen Syariah Berbasis Sekolah di Madrasah Ibtidaiyah Negeri (MIN ) 2 Sukoharjo dan Madrasah Ibtidaiyah Negeri (MIN) 4 Sukoharjo dengan 11 komponennya, maka penulis kemudian akan meneliti Implementasinya, apakah Implementasi yang dilakukan sudah sesuai dengan Strategi yang dicanangkan atau tidak. Proses demokratisasi pendidikan ini harus dilalui oleh setiap sekolahan. Lepas dari paham atau tidak paham MBS harus dilaksanakan meskipun pada tahap awal dan berlatih.

Dengan adanya kesempatan yang diberikan pemerintah untuk meberdayakan komunitas sekolah , maka tidak ada alasan untuk bermalas - malasan bagi para praktisi pendidikan baik kepala sekolah maupun guru untuk mencurakan pikiran dan tenaganya dalam rangka mendorong kemajuan pad sekolahnya masing - masing. Implementasi MBS ini merupakan wacana pendidkan yang berafiliasi terhadap kebutuhan masyarakat dan kondisi alam didaerah. MBS dipahamai sebagai media atau cara taktis pemerintah dalam rangka pemberdayaan masing - masing sekolah. Upaya - upaya itu dilakukan dengan tanpa mengabaikan eksistensi dan karakteristk budaya yang ada didaerah itu. Adapun rumusan - rumusan tentang 
target dan orientasi pendidikan itu dalam tujuan pendidikan nasional.

Dimana dalam tujuan pendidikan nasional telah dirumuskan bahwa: "Pendidikan Nasional bertujuan mencerdaskan kehidupan bangsa dan mengembangakan manusia seutuhnya, yaitu manusia yang beriman bertaqwa kepada Allah SWT, dan berbudi luhur, memilki pengetahuann dan ketrampilan, kesehatan jasmani dan rohani, kepribadian yang mantap da mandiri serta rasa tanggung jawab kemasyarakatan dan kebangsaan. Dalam tujuan pendidikan nasional jelas disebutkan bahwa seluruh anak - nak bangsa merupakan modal penting bagi pembangunan nasional.

Pembangunan Nasional tidak diarahkan pada pembangunan materiil saja , akan tetapi pembangunan nasional diwujukan dalam sebuah cita - cita masyarakat " civil sociaety" yaitu masyrakat adil berkemakmuran dan makmur dalam berkeadilan secara menyeluruh. Sebagai SDM yang harus diperdayakan dalam rangkai tercapainya tujua pendidikan nasional sebagaimana yang diungkapkan diatas , maka peningkatan Sualitas pendidikan menjadi sangat penting. Dengan kata lain bahwa agenda pendidikan nasional adalah "mempersiapkan pibadi-pribadi untuk masa depan" (preparing individuals for future).

\section{Madrasah Ibtidaiyah Negeri (MIN) 2 Sukoharjo}

Terkait dengan pemahaman konseptual dan aplikasi Kepala Madrasah MI Negeri 2 Sukoharjo tentang MBS, memang sebelumnya kepala mengikuti pelatihan MBS dibeberapa instasi baik Depag maupun Diknas, dan kemudia belaiu menyampaikan kepada guru, karyawan dan masyarakat sekitar.dan bagi beliau untuk pemahaman MBS kepada guru dan karyawan serta masyarakat sekarang ini relatif mudah karena , memang sejak awal mereka sudah dipahamkan dari Kepala Sekolah.

Kepala sekolah pada awalnya juga harus mngikuti pelatihan MBS dibeberapa instasi baik Depag maupun Diknas, dan kemudian belaiu menyampaikan kepada guru ,karyawan dan masyarakat sekitar.dan bagi beliau untuk pemahaman MBS kepada guru dan karyawan serta masyarakat sekarang ini relatif mudah karena, memang sejak awal mereka sudah dipahamkan dari Kepala Sekolah yang pertama.(Wawancara dengan Kepala Sekolah MIN 2 Sukoharjo). Kepala MI Negeri 2 Sukoharjo juga mengatakan bahwa, Masyarakat sekarang sudah memehami tentang pentingnyanya MBS dan dampak secara langsung Implementasi MBS, ketika beliau menyampaiakan kepada masyarakat tentang MBS ,sebagaian masyarakat mendukungnya dan setelah beberapat tahun berjalan mereka sebagian masyarakat mengatakan bahwa dengan adanya implementasi MBS dapat dirasakan peningkatan pola dalam pembelajarannya dimana SDM di MI Negeri 1 Sukoharjo ini terus melakukan pembenahan pembenahan secara bertahap, Kepala Sekoah, Guru, Staf dan Stake Holders berjalan kompak melakukan perubahan.

Penerapan MBS di MI Negeri 2 Sukoharjo ini bersifat rintisan awal dengan berbagai langkah, yaitu menyamakan persepsi, menanamkan dasar keluasan cara pandang dan keterbukaan, konsisten pada struktural, dan konsisten pada prosedur kebijakan ditingkat sekolah, oleh karenanya Kepala Sekolah MI Negeri 2 Sukoharjo ini berusaha dengan komitmen yang kuat untuk menerapkannya. Dari beberapa indikator yang harus dilaksanakan dalam menunjang implementasi beliau telah melaksanakan Peningkatan kualitas guru dengan mengirimkan keberbagai macam pelatihan dalam rangka meningkatkan kualitas SDM, atau mengadakan pelatihan sendiri disekolah dan pelatihan pegawai.

\section{Madrasah Ibtidaiyah Negeri (MIN) 4 Sukoharjo}

Madarsah Ibtidaiyah (MI) yang berlandaskan pada agama dan syariah khusunya MIN 4 Sukoharjo adalah meliputi subtansi pembelajarn yang ditempuh dari dalam satu jenjang pendidikan selama enam tahun mulai kelas 1 sampai dengan kela VI. Struktur Kurikulum MI disusun berdasarkan standar kompetensi lulusan dan standar kopetensi mata pelajaran dan integral terhadap basis agama dan syariah dengan ketentuan sebagai berikut (Buku besar Profil MIN) :

Pertama, Kurikulum MI Negeri 4 Sukoharjo memuat 8 Mata pelajaran, muatan lokal, dan pengembangan diri. Muatan lokal merupakan kegiatan kurikuler untuk mengembangkan potensi yang disesuaikan dengan ciri khas dan potensi daerah, termasuk keunggulan daerah , yang materinya tidak dapat dikelompokan kedalam mata pelajaran yang ada. Subtansi muatan lokal ditentukan oleh satuan pendidikan.

Kedua, Pengembangan diri bukan merupakn mata pelajaran yang harus diasuh oleh guru Pengembangan diri bertujuan memberikan kesempatan kepada peserta didik untuk mengembangkan dan mengekprsikan diri sesuai 
kebutuha, bakat, minat setiap peserta didik sesuai dengan kondisi sekolah. Kegiatan pengembangan diri difasilitasi dan dibimbing oleh guru atau konselor,guru,atau tenaga kependidikan yang dapat dilakukan dalam bentuk ekstrakulikuler.

Ketiga, Subtansi mata pelajaran yang terpadu berbasis agama Islam.

Keempat, Pembelajaran kelas 1 s/d 3 dilaksanakan dengan pembelajaran tematik, sedangkan pada kelas 4 s/d 6 dilaksanakan dengan pendekatan mata pelajaran yang berbasis pada agama sehingga anak didik senantiasa terikat pada agama.

Kelima, Jam pembelajaran untuk setiap mata pelajaran dialokasikan sebagaimana tertera dalam struktur kurikulum.Satuan pendidikan dimungkinkan menambah maksimum empat jam pembelajaran perminggu secara keseluruhan. Alokasi waktu jam pembelajaran satu jam adalah 35 menit, minggu effektif dalam satu tahun pelajaran adalah dua semester yaitu $34-38$ minggu, dengan catatan waktu tersebut tetap memperhatikan waktu untuk beribadah Sholat.

\section{Sarana dan Prasarana Madarasah Ibtidaiyah Negeri (MIN) 2 Sukoharjo dan Madarasah Ibtidaiyah Negeri (MIN) 4 Sukoharjo.}

Madrasah sebagai pusat kegiatan proses belajar mengajar, keberhasilanya tidak dapat terlepas dari sarana dan prasarana pendidikan yang merupakan alat penunjang baku, Kepala Madrasah sebagai pimpinan madrasah wajib memenuhi kebutuhan sarana dan prasarana sesuai kebutuhan madrasah. Sebelumnya juga Kepala beserta Waka Sarana Prasarana juga telah menjalankan 4 (empat) aspek yang berkaitan dengan Sarana dan Prasarana yang ada dalam Buku Panduan Manajemen Berbasis Madrasah yang ditulis oleh Mulyasa yaitu :

Pertama, Perencanaan; Mengidentifikasi Kebutuhan Sarana Prasarana pendidikan yang dibutuhkan madrasah, menetapkan prioritas kebutuhan sarana prasarana pendidikan.

Kedua, Pengadaan; Menuangkan dalam bentuk program, Mengusulkan pengadaan Sarana dan Prasarana pendidikan kepada pihak yang terkait.

Ketiga, Penggunaan; Mengadakan Sarana dan Prasarana pendidikan sesuai dengan prioritas dan kemampuan madrasah, Mendistribusikan dan pendayagunaan sarana prasarana secara optimal.
Keempat, Perawatan; Melaksanakan perawatan dan pemeliharaan secara teratur dan berkesinambungan (Buku Rencana Kerja Waka Sarana Prasarana dan Lingkungan Hidup).

Kesaadaran bahwa pendidikan yang semakin maju akibat laju perkembangan ilmu pengetahuan dan tehnologi, maka sekolah atau madrasah dituntut untuk menyediakan sarana dan prasarana sesuai ilmu pengetahuan dan tehnologi agar madrasah dapat memenuhi kebutuhan masyarakat. Serta senantiasa memiliki sikap mental yang terikat kepada syariah, sehingga tercipta kejujuran dan keikhlasan. Implementasi Manajemen Berbasis Sekolah dalam meningkatkan Mutu Pendidikan di Madrasah Ibtidaiyah Negeri (MIN) 2 Sukoharjo dan Madrasah Ibtidaiyah Negeri (MIN) 4 Sukoharjo secara umum menunjukan keberhasilanya, hal tersebut terlihat dengan tercapainya hasil implementasi dari strategi strategi yang telah dibuat sebelum Implementasi Manajemen Berbasis Sekolah dilaksanakan.

Adapun di MIN 4 Sukoharjo sendiri dalam Implementasinya sudah dirinci dalam beberapa komponen - komponen yang merupakan Input dari MBS yaitu Kepala Sekolah, Guru, Karyawan, Siswa, Sarana Prasarana, Hubungan dengan Masyarakat, Kurikulum, dan Kegian Belajar Mengajar yang kemudian stelah melaui proses dapat menghasilkan out put dan out came. Out put dapat terlihat dari prestasi akademik, non akademik yang diraih, dan kemampuan spritual.Prestasi akademik misalnya nilai ulangan harian rata - rata tiap ujian mid semester, semester atau kenaikan kelas selalu baik, diraihnya juara tiap mengikuti lomba baik tingkat sekolah, kelurahan, kecamatan, kabupaten, propinsi ataupun tingkat nasional.

Sedangkan prestasi non akademik yang diraih adalah kemahiran siswa mulai dari kelas 1 yaitu dengan menggunakan tehnologi informasi yang berupa komputer, kemenangan siswa dalam lomba dibidang kesenian, olah raga dan ketrampilan.Kemampuan bidang spiritual adalah munculnya siswa- siswi yang berakhlakul karimah , hafalnyanya siswa mebaca juza'ama dan doa, siswa terbiasa mengucap dan menjabat tangan jika bertemu teman dan guru, membiasan melakukan sholat sunah dan wajib disekolah, membiasakan berbicara lemah lembut dan sopan,membiasakan menengok dan mendoakan jika teman sakit dan masih banyak hal yang baik yang mencerminkan keberhasilan pendidikan keagamaan. 


\section{Jurnal Ilmiah Ekonomi Islam, 7(01), 2021, 331}

Sedangkan Outcame-nya adalah dapat dilihat dari dua indikator yaitu indikator pertama adalah kesempatan melanjutkan sekolah, yang dimakud adalah kemana setelah lulus dari MIN 2 dan MIN 4 Sukoharjo, dan indikator kedua adalah pengembangan sikap dan tingkah laku lulusan. Kesempatan melanjutkan sekolah, dari data yang diperoleh menunjukan bahwa hampir dari lulusan MIN 2 dan MIN 4 Sukoharjo diterima di SMP Negeri dan sebagian dipondok pesantren atau SMP IT yang unggulan.

\section{KESIMPULAN}

Konsep Implementasi Manajemen Syariah Berbasis Sekolah (MBS) yang diterapkan di Madrasah Ibtidaiyah Negeri 2 Sukoharjo dan Madrasah Ibtidaiyah Negeri (MIN) 4 Sukoharjo sudah cukup baik. Beberapa komponen yang ada dalam konsep MBS sudah dapat dilasanakan dengan baik, seperti Kepemimpinan Kepala Sekolah yang demokratis, Kepala Sekolah telah mampu menjalankan peran sebagai pendidik, manajer, pemimpin,administrator, supervisor, inovator dan motivator dengan baik.Selain itu Peran aktif masyarakat juga telah nampak hal tersebut dapat dilihat dengan bantuan yang diberikan kepada MIN 2 Sukoharjo dan MIN 4 Sukoharjo baik materiil maupun non materiil. Juga peran serta guru yang secara berrsama sama terus meningkatkan kualitasnya dengan berbagai macam kegiatan. Strategi - Strategi Implementasi yann dibuat Madarasah Ibtidaiyah Negeri 2 dan 4 sukoharjo yang, juga cukup efektif misalnya dalam meningkatkan pengembangan mutu siswa di Madrasah, Strategi peningkatan kualitas siswa dengan berlandaskan nilai-nilai agama.

\section{UCAPAN TERIMAKASIH}

Terimakasih kami haturkan kepada Ketua LPPM ITB AAS Indonesia dan khususnya kepada dewan redaksi Jurnal Ilmiah Ekonomi Islam ( JIEI) ITB AAS Indonesia yang telah memberikan kesempatan, sehingga tulisan saya bisa diterbitkan.

\section{REFERENSI}

Ahmad Zaini Aziz. (2015). Manajemen Berbasis Sekolah (Alternatif Peningkatan Mutu Pendidikan Madrasah). Ekspose: Jurnal Penelitian Hukum Dan Pendidikan, 8(1), 69-92. https://doi.org/10.30863/ekspose.v17i2.117

Aminah, S., AR, M., \& Usman, N. (2015). Implementasi Manajemen Berbasis Sekolah dalam meningkatkan mutu pendidikan pada MTsN kota Lhokseumawe. Jurnal Administrasi Pendidikan Program Pascasarjana Unsyiah, 3(2), 1-11.

Arif, M. (2013). Manajemen Madrasah Dalam Upaya Peningkatan Mutu Pendidikan Islam. Epistemé: Jurnal Pengembangan Ilmu Keislaman, 8(2). https://doi.org/10.21274/epis.2013.8.2.415-438

Athiyah, C. U. (2019). Implementasi Manajemen Berbasis Sekolah sebagai alternatif desentralisasi pendidikan di MAN 4 Jakarta. Andragogi: Jurnal Diklat Teknis Pendidikan Dan Keagamaan, 7(1), 130-145.

https://doi.org/10.36052/andragogi.v7i1.82

Aziz, A. Z. (2018). Manajemen Berbasis Sekolah (alternatif peningkatan mutu Pendidikan Madrasah). El-Tarbawi, $17(2), 601$. https://doi.org/10.30863/ekspose.v17i2.117

Erdiyanto, Asha, L., Warsah, I., \& Hamengkubuwono. (2020). Manajemen Peningkatan Mutu pendidikan di Madrasah Aliyah Negeri 02 Lebong Bengkulu. Islamic Management: Jurnal Manajemen Pendidikan Islam. https://doi.org/10.30868/im.v3i02.840

Fadhli, M. (2017). Manajemen peningkatan mutu pendidikan. TADBIR: Jurnal Studi Manajemen Pendidikan, 1(02).

Khoiri, N. (2014). Revitalisasi dan optimalisasi manajemen Madrasah sebagai pendidikan Islam menuju pendidikan alternatif. Jurnal Tarbawi, 11(1), 21-46.

Lee, D. H. L., \& Chiu, C. S. (2017). "School banding”: Principals' perspectives of teacher professional development in the school-based management context. Journal of Educational Administration, 55(6), 686-701. https://doi.org/10.1108/JEA-022017-0018

Maimun, A., \& Fitri, A. Z. (2010). Madrasah unggulan: Lembaga pendidikan alternatif di era kompetitif. Malang: UIN Maliki Press. 
Maya, R., \& Lesmana, I. (2018). Pemikiran prof. Dr. Mujamil Qomar, M.Ag tentang manajemen pendidikan Islam. Islamic Mangement, I(2), 291-316.

Munajat, N. (2016). Kebijakan Manajemen Berbasis Madrasah dalam Peningkatan Mutu Pendidikan Islam. Jurnal Pendidikan Dasar Islam ALBIDAYAH, 8(2), 154-163.

Nur, M., Harun, C. Z., \& Ibrahim, S. (2016). Pendidikan Pada SDN Dayah Guci Kabupaten Pidie. Jurnal Administrasi Pendidikan, 4(1), 93103.

Patras, Y. E., Agus Iqbal, Papat, \& Rahman, Y. (2019). Meningkatkan kualitas pendidikan melalui kebijakan Manajemen Berbasis Sekolah dan tantangannya. Jurnal Manajemen Pendidikan, 7(2), 800-807.

Sulaiman, Hasmiana, \& Asmaini. (2015). Implementasi Manajemen Berbasis Sekolah (MBS) dalam meningkatkan profesionalisme guru Di SD Negeri 10 Banda Aceh. Jurnal Pesona Dasar, 2(4), 33-43. https://doi.org/10.24815/pear.v7i2.14753
Sumadi, S. (2017). Peran Manajemen Syariah Terhadap Peningkatan Kepuasan Pelanggan Pada Rumah Sakit Islam Di Kota Surakarta. Jurnal Ilmiah Ekonomi Islam, 3(02), 112-124.

Sunanto, S. (2015). Implementasi Manajemen Berbasis Sekolah dalam peningkatan mutu pendidikan pada SMP Negeri 19 p ercontohan Banda Aceh. Intelektualita, 3(1), 243277.

Suparlan. (2013). Manajemen berbasis sekolah: dari teori sampai dengan praktik. Jakarta: Bumi Aksara.

Yahya, F. A. (2015). Problem manajemen Pesantren, Sekolah dan Madrasah: Problem Mutu dan Kualitas Input-Proses-Output. El-Tarbawi, 8(1), 93-109. 